Journal of the Electrochemical Society, Vol. 150, No. 1, 2003, pp. B1-B9.

ISSN: (Print 0013-4651) (Online 1945-7111)

DOI: $10.1149 / 1.1524172$

http://www.electrochem.org/

http://scitation.aip.org/JES

http://scitation.aip.org/getpdf/servlet/GetPDFServlet?filetype=pdf\&id=JESOAN0001500000010000B1000001\&idty pe $=$ cvips \&prog $=$ normal

(C) The Electrochemical Society, Inc. 2003. All rights reserved. Except as provided under U.S. copyright law, this work may not be reproduced, resold, distributed, or modified without the express permission of The Electrochemical Society (ECS). The archival version of this work was published in Journal of the Electrochemical Society, Vol. 150, No. 1, 2003, pp. B1-B9.

\title{
Electrochemical Quartz Crystal Microbalance Study of Corrosion of Phases in AA2024
}

\section{Y. Baek and G. S. Frankel}

Fontana Corrosion Center, Department of Materials Science and Engineering, The Ohio State University

The electrochemical quartz crystal microbalance (EQCM) was used to directly measure the dissolution rate at cathodic potentials, and thus the cathodic corrosion rate, of thin-film analogs of phases in AA2024. Thin films of pure $\mathrm{Al}, \mathrm{Al}-4 \% \mathrm{Cu}$, and $\mathrm{Al}_{2} \mathrm{Cu}$ were studied in $0.1 \mathrm{M} \mathrm{NaCl}$ containing $0,10^{-4}$, or $10^{-2} \mathrm{M} \mathrm{Cr}_{2} \mathrm{O}_{7}$. A range of cathodic potentials was studied for each material. The true cathodic current density was calculated from the difference of the net current density and the dissolution rate, which was determined by the EQCM. For pure $\mathrm{Al}$ and $\mathrm{Al}-4 \mathrm{Cu}$, the cathodic corrosion rate was large relative to the net current density, so the true cathodic current density was considerably larger than the measured net current density. The cathodic current density was almost identical to the net current density for $\mathrm{Al}_{2} \mathrm{Cu}$ because the dissolution rate was very small compared to the cathodic reaction rate. Various potentials in the limiting oxygen reduction reaction region were examined, but the effect of the applied potential was small. The presence of dichromate in solution decreased both the cathodic corrosion rate and the cathodic current density on these thin-film analogs. In particular, it decreased more effectively the cathodic reaction rate on $\mathrm{Al}_{2} \mathrm{Cu}$, which can support faster cathodic reaction rates.

The corrosion behavior of high strength $\mathrm{Al}$ alloy 2024 depends strongly on the cathodic activity of $\mathrm{Cu}$-rich intermetallic particles such as $\theta$ phase $\left(\mathrm{Al}_{2} \mathrm{Cu}\right), \mathrm{S}$ phase $\left(\mathrm{Al}_{2} \mathrm{CuMg}\right)$, and particles of varying composition containing $\mathrm{Al}, \mathrm{Cu}, \mathrm{Mn}$, and Fe. ${ }^{1,2}$ During the corrosion of AA2024, Cu-containing intermetallic compounds (IMCs) act as preferred cathodic sites for oxygen reduction and the anodic sites are active $\mathrm{S}$-phase particles and the Al matrix. ${ }^{3}$ Reduction reactions at the cathodic sites lead to the development of high $\mathrm{pH}$ zones near IMCs and the surrounding region. The increased local $\mathrm{pH}$ promotes dissolution of the Al matrix near the cathodic IMCs, causing localized attack at the periphery of $\mathrm{Cu}$-containing intermetallic particles, 2,4-6 and may also result in dealloying of IMCs themselves.

Chromate effectively inhibits corrosion of $\mathrm{Al}$ alloys by forming a protective surface film and/or its intrinsic effects on the corrosion kinetics. For instance, $\mathrm{Cr}(\mathrm{VI})$ and chromate film on AA2024 was found to increase the corrosion resistance by several orders of magnitude ${ }^{7}$ and to act as a protective barrier for anodic dissolution of the $S$ phase and Al matrix and cathodic inhibitor at local cathodes. It has been also suggested that chromate inhibits the oxygen reduction reaction (ORR). ${ }^{9,10}$

However, it is very difficult to determine exactly the cathodic kinetics on $\mathrm{Al}$ and $\mathrm{Al}$ alloys using only electrochemical techniques. Even during cathodic polarization with a net negative current, the Al oxide film dissolves chemically by the alkalinity generated by the hydrogen evolution and oxygen reduction reactions. The reformation of oxide film involves Al 
oxidation reactions, which produce an anodic current. This phenomenon is known as cathodic corrosion. ${ }^{11-13}$ Since the net current density measured by potentiostats is the algebraic sum of all of the electrochemical reactions, it is less than the true cathodic current density if the anodic reaction rate, or cathodic corrosion rate, is significant in magnitude.

The cathodic corrosion rate can be accurately determined by the electrochemical quartz crystal microbalance (EQCM) technique, which provides submonolayer resolution of mass changes occurring at an electrode surface as well as the current for a sample under controlled potential. The EQCM actually measures the changes in resonant frequency of the quartz crystal substrate, which can be converted into mass change using the Sauerbrey equation. However, the resonant frequency can be also influenced by changes in the density and viscosity of the nearby solution and changes in surface roughness of the electrode. ${ }^{15,16}$

Because of its extremely high mass sensitivity and in situ capability, the EQCM provides a unique approach for examining electrode dissolution, and has been applied to the study of corrosion and corrosion inhibition. ${ }^{17-22}$ Schumacher et al. studied the mechanism of electrochemical dissolution of copper in oxygenated sulfuric acid using an in situ EQCM, and found that the copper dissolution rate is linearly proportional to the concentration of $\mathrm{O}_{2}$ and $\mathrm{H}^{+}$. Pickering et al. ${ }^{18}$ investigated copper corrosion in acid solution in the absence or presence of various inhibitors by EQCM, and showed the effect of various inhibitors on the copper corrosion.

In this study, thin-film Al and thin-film analogs of the Al matrix in AA2024 and $\theta$ phase were fabricated using the flash evaporation technique. The ORR rates and cathodic corrosion behavior of the thin-film samples were studied using the EQCM technique. The thin-film analogs were potentiostatically polarized at different cathodic potentials in $0.1 \mathrm{M} \mathrm{NaCl}$ solution with different concentrations of chromate. The EQCM allows direct determination of the cathodic corrosion rate from the mass loss rate, and the true cathodic reaction rate from the difference between the net current density and cathodic corrosion rate. The effect of chromate on the cathodic corrosion rate and the true cathodic reaction rate was investigated as a function of the applied potential, the chromate concentration, and the electrode material.

\section{Experimental}

Thin films of pure $\mathrm{Al}, \mathrm{Al}_{2} \mathrm{Cu}$, and $\mathrm{Al}-4 \mathrm{Cu}$ were deposited by the flash evaporation technique on $10 \mathrm{MHz}$ AT-cut quartz crystals. The starting materials for flash evaporation were prepared from pure $\mathrm{Al}$ and $\mathrm{Cu}$ pellets using an induction furnace. A cast alloy ingot was crushed into a powder form and loaded into the evaporation chamber. The base pressure of the chamber prior to evaporation was about $6 \times 10^{-8}$ Torr, and the operating pressure was less than $2 \times 10^{-7}$ Torr. The nominal thickness of the samples was $500 \mathrm{~nm}$. Details of the flash evaporation technique and characterization of the thin films are given elsewhere. ${ }^{23}$

Solutions of $0.1 \mathrm{M} \mathrm{NaCl}$ ( $\mathrm{pH}$ 6.2) with and without different concentrations of $\mathrm{Na}_{2} \mathrm{Cr}_{2} \mathrm{O}_{7}$ were prepared from certified A.C.S. grade chemicals and deionized water. The $\mathrm{pH}$ of the dichromate-containing solutions was adjusted to 6.2 by the addition of $\mathrm{NaOH}$. A Pt electrode mesh and a saturated calomel electrode (SCE) were used as counter electrode and reference electrode, respectively, to complete the three-electrode cell. 
Table I. Weight and atomic percentages of thin film analogs of $\mathrm{Al}-4 \mathrm{Cu}$ and $\mathrm{Al}_{2} \mathrm{Cu}$.

\begin{tabular}{lcc} 
Phases & $\mathrm{Al}(\mathrm{wt} \% /$ atom \%) & $\mathrm{Cu}(\mathrm{wt} \% /$ atom \%) \\
\hline $\mathrm{Al}-4 \mathrm{Cu}$ & $96.1 / 98.2$ & $3.9 / 1.8$ \\
$\mathrm{Al}_{2} \mathrm{Cu}$ & $45.5 / 66.3$ & $54.5 / 33.7$
\end{tabular}

A commercial electrochemical quartz crystal microbalance system (Elchema EQCN-900) was used for simultaneous electrochemical and mass change measurements. The thin-film coated quartz crystal was placed in a crystal holder and the electrical contact between the thin-film electrode and wire leads was made by colloidal silver, which was isolated from the solution by silicone resin. The crystal holder mounted with the quartz crystal was placed horizontally into an electrochemical cell made of Plexiglas. The electrochemical cell was placed in a Faraday cage to minimize electromagnetic interference from the surroundings. Each EQCM experiment was repeated at least three times to verify its reproducibility. It should be noted that no evidence of localized attack such as pitting corrosion was observed for these experiments, which were performed at relatively low potentials in the cathodic region.

Potentiodynamic and potentiostatic polarization experiments were performed at cathodic potentials in each solution after waiting at least $3 \mathrm{~min}$ at the open-circuit potential (OCP). Potentiodynamic polarization scans started $50 \mathrm{mV}$ above the OCP at a scan rate of $1 \mathrm{mV} / \mathrm{s}$. For potentiostatic polarization, potential was stepped from the OCP to cathodic potentials, which were chosen to be in the limited ORR region.

\section{Results and Discussion}

Characterization of thin film analogs.-Table I shows the composition of thin film analogs of pure Al, Al matrix, and $\theta$ phase by weight and atomic percents (atom \%) of each element as determined by energy dispersive spectroscopy (EDS) in a scanning electron microscope. The results indicate that the composition of thin films was well controlled by the flash evaporation technique and in good agreement with the compositions of the same phases in the bulk Al alloy. The content of oxygen was controlled to less than $1 \%$ by using crushed powder from a cast ingot and maintaining a low chamber pressure during the evaporation process. It has been reported that $\mathrm{Al}$ thin films deposited with a base pressure of $2 \times 10^{-7}$ Torr or better behave very similarly to the bulk material. Assuming that the effect of any structural difference is small and chemical composition is dominant in electrochemical behavior, it is reasonable to expect that the behavior of these thin-film analogs would be representative of those of the phases of the same composition found in bulk $\mathrm{Al}$ alloys. In another study, thin-film analogs of $\mathrm{Mg}(\mathrm{Zn}, \mathrm{Cu}, \mathrm{Al})_{2}$ inter-metallic particles in $7 x x x \mathrm{Al}$ alloys were successfully used to study the behavior of this phase.

Cathodic polarization of thin-film analogs.-Potentiodynamic polarization experiments were performed on the thin-film samples of pure $\mathrm{Al}, \mathrm{Al}-4 \mathrm{Cu}, \mathrm{Al}_{2} \mathrm{Cu}$, and on AA2024-T3 in 0.1 $\mathrm{M} \mathrm{NaCl}$. Cathodic polarization curves are shown in Fig. 1. The OCPs and ORR rates significantly increased as the content of $\mathrm{Cu}$ in the analogs increased from zero to 33 atom $\%$. The OCP was higher for $\mathrm{Al}_{2} \mathrm{Cu}$, and lower for pure $\mathrm{Al}$ and $\mathrm{Al}-4 \mathrm{Cu}$ compared to AA2024-T3. The net current density in the limiting ORR region was very low, less than $5 \mu \mathrm{A} / \mathrm{cm}^{2}$, for pure $\mathrm{Al}$ even at potentials as low as $-1.5 \mathrm{~V}_{\mathrm{SCE}}$. The limiting net current densities increased with increasing $\mathrm{Cu}$ content, but the values were similar for $\mathrm{Al}_{2} \mathrm{Cu}$ and AA2024-T3. The exchange current densities 
for hydrogen evolution also increased with $\mathrm{Cu}$ content so that the onset of hydrogen evolution occurred at higher potentials. The hydrogen evolution reaction (HER) started to occur below $1.6 \mathrm{~V}_{\mathrm{SCE}}$ for pure Al.

The ORR rate was significantly enhanced on the $\mathrm{Al}-4 \mathrm{Cu}$ compared to that on pure $\mathrm{Al}$, resulting from the addition of only $4 \mathrm{wt} \%$ (or 2 atom \%) $\mathrm{Cu}$ in the solid solution. The limiting ORR rates were clearly not the true mass-transport-limited rates on these Al alloys because such a rate would not depend on the electrode material. This has been observed by others and attributed to kinetic limitations imposed by the oxide film. ${ }^{6,26}$ This result indicates that the cathodic activity of Al-Cu alloy strongly depends on the content of $\mathrm{Cu}$ in the alloy.

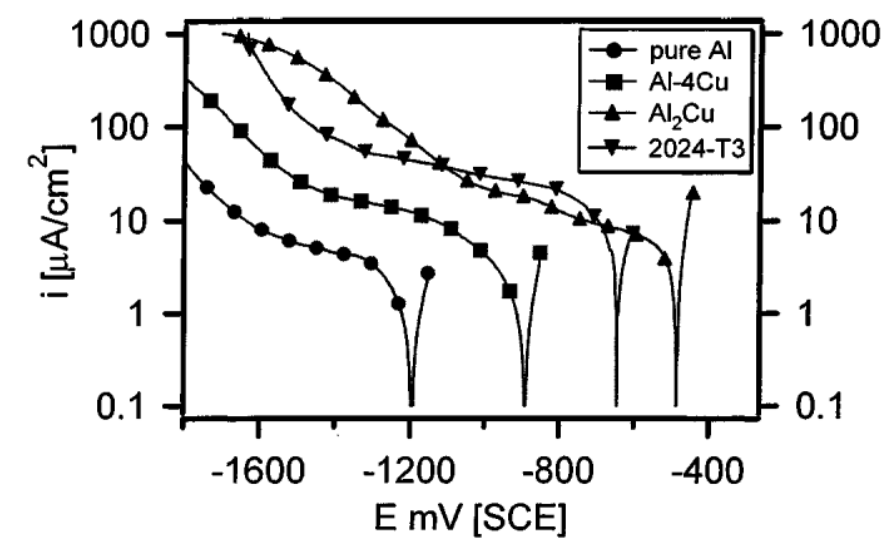

Figure 1. Potentiodynamic cathodic polarization curves for pure $\mathrm{Al}, \mathrm{Al}-4 \mathrm{Cu}, \mathrm{Al}_{2} \mathrm{Cu}$, and $\mathrm{AA} 2024-\mathrm{T} 3$ in $0.1 \mathrm{M} \mathrm{NaCl}$ (pH 6.2) at a scan rate of $1 \mathrm{mV} / \mathrm{s}$.

Potentiostatic polarization experiments were performed with the EQCM, simultaneously measuring mass changes of the electrode as well as current. Figure 2 shows net current density and mass change as a function of time for pure $\mathrm{Al}$ in $0.1 \mathrm{M} \mathrm{NaCl}$ at different potentials in the limiting ORR region. Even though the net or measured current was cathodic or negative, the mass decreased rapidly at the beginning of cathodic polarization and then reached a slower constant rate of decrease. As mentioned above, cathodic corrosion of $\mathrm{Al}$ occurs due to a local $\mathrm{pH}$ increase near the electrode surface resulting from oxygen reduction and/or hydrogen evolution. The aluminum oxy/hydroxide film at the oxide/solution interface is dissolved chemically by the high $\mathrm{pH}$ solution, which stimulates reformation of $\mathrm{Al}$ oxide at the metal/oxide interface by an $\mathrm{Al}$ oxidation process. ${ }^{11}$ The net current density was also large at the beginning of polarization, and then became smaller and almost constant at longer times. A steady state with constant mass loss rate and net current density was developed, in which the rate of chemical dissolution of oxide film was balanced by the rate of oxide film formation. While the mass loss of pure Al showed weak dependence on applied potential, the net current density showed a strong dependence on applied potential. 

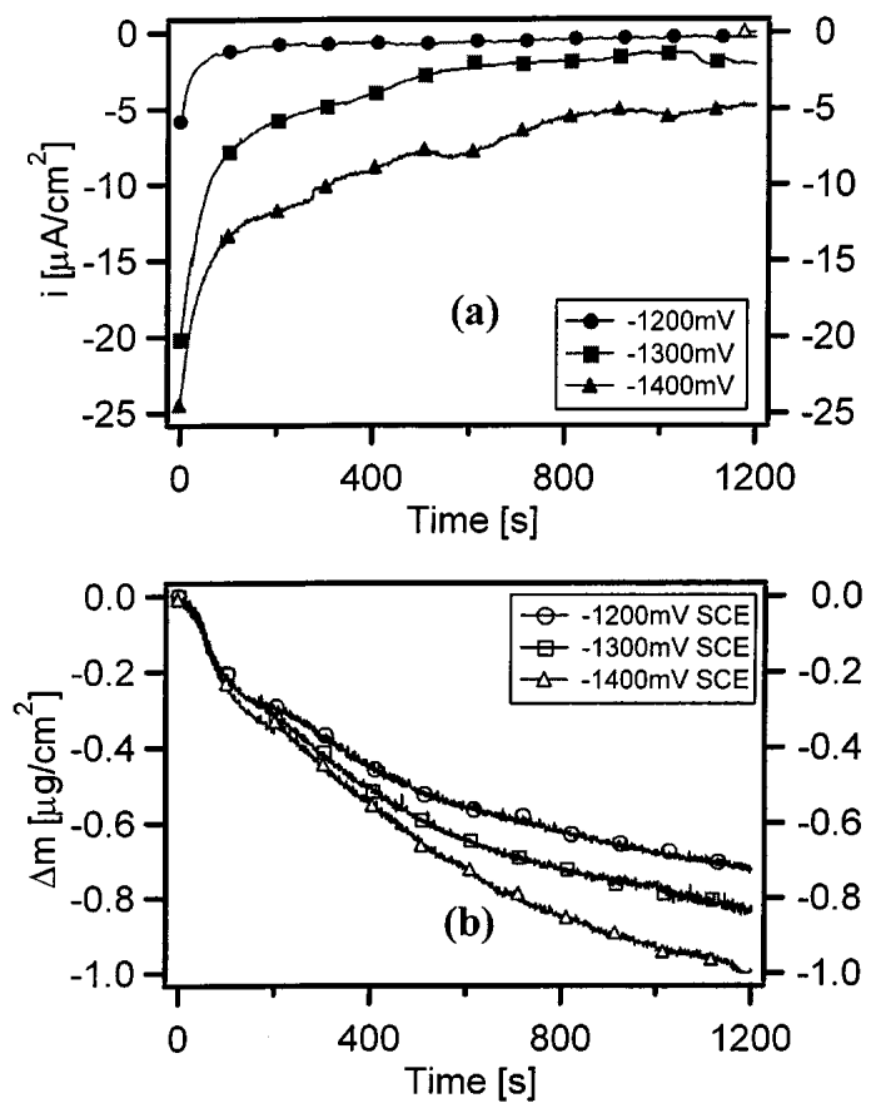

Figure 2. (a) Net current density and (b) mass change for pure Al during potentiostatic polarization in $0.1 \mathrm{M} \mathrm{NaCl}$ (pH 6.2).

The net current density and mass change for $\mathrm{Al}-4 \mathrm{Cu}$ thin films during potentiostatic polarization in the limiting ORR region in $0.1 \mathrm{M} \mathrm{NaCl}$ are shown in Fig. 3. Note that the limiting ORR region for $\mathrm{Al}-4 \mathrm{Cu}$ is at higher potentials than for pure $\mathrm{Al}$. As for the case of pure $\mathrm{Al}$, the net current density decreased with time and reached steady-state values after several minutes. The net current density for $\mathrm{Al}-4 \mathrm{Cu}$ exhibited a weaker potential dependence than for pure $\mathrm{Al}$ and was higher than for pure $\mathrm{Al}$ even in higher potential ranges. The mass decreased at a constant rate after an initial transient period, similar to pure Al. In general, the mass loss was higher for $\mathrm{Al}-4 \mathrm{Cu}$ than for pure $\mathrm{Al}$. The increased cathodic reactivity and resultant mass loss of $\mathrm{Al}-4 \mathrm{Cu}$ compared to pure $\mathrm{Al}$ can be explained by the influence of copper. The cathodic reaction, oxygen reduction, is enhanced not only by the addition of $\mathrm{Cu}$ into the alloy, but also by the subsequent increase in surface copper concentration due to selective dissolution of $\mathrm{Al}$ from the oxide. 

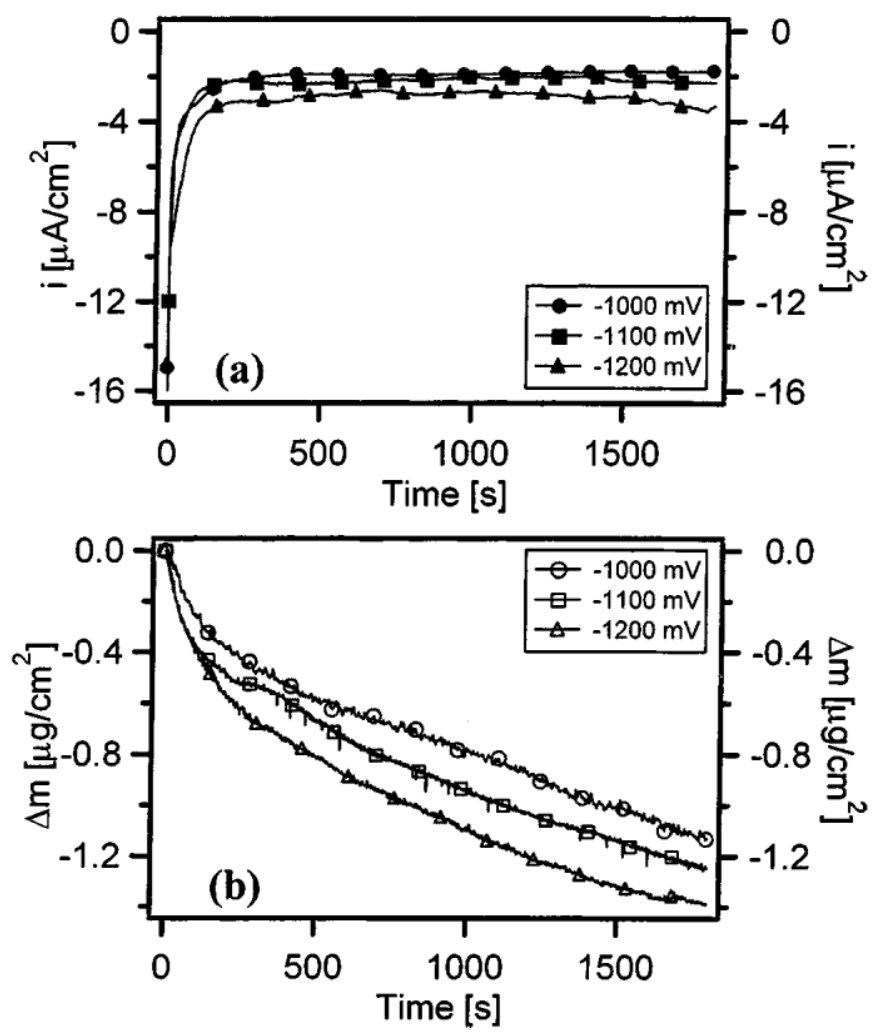

Figure 3. (a) Net current density and (b) mass change for $\mathrm{Al}-4 \mathrm{Cu}$ during potentiostatic polarization in $0.1 \mathrm{M} \mathrm{NaCl}$ (pH 6.2).

Figure 4 shows the net current density and mass change for a thin film of $\mathrm{Al}_{2} \mathrm{Cu}$ during potentiostatic polarization in the limiting ORR region in $0.1 \mathrm{M} \mathrm{NaCl}$. The net current density was much higher for $\mathrm{Al}_{2} \mathrm{Cu}$ than for pure $\mathrm{Al}$ and $\mathrm{Al}-4 \mathrm{Cu}$ even at higher potentials. The mass increased rapidly at the beginning of the polarization, and then decreased slowly at longer times. Experiments on $\mathrm{Au}$ thin films suggest that the apparent increase in mass for $\mathrm{Al}_{2} \mathrm{Cu}$ following a change in potential in the cathodic direction is primarily caused by a rearrangement of the electrical double layer as the potential crosses the potential of zero charge. ${ }^{23}$

Effect of chromate on cathodic kinetics. - The effects of chromate on cathodic kinetics for pure $\mathrm{Al}, \mathrm{Al}-4 \mathrm{Cu}$, and $\mathrm{Al}_{2} \mathrm{Cu}$ were measured in $0.1 \mathrm{M} \mathrm{NaCl}$ containing $10^{-4}$ or $10^{-2} \mathrm{M}$ $\mathrm{Na}_{2} \mathrm{Cr}_{2} \mathrm{O}_{7}$, with the initial $\mathrm{pH}$ of the solutions adjusted to 6.2 by the addition of $\mathrm{NaOH}$. Potentiodynamic polarization curves of pure $\mathrm{Al}$ in $0.1 \mathrm{M} \mathrm{NaCl}$ solution with different concentrations of dichromate are shown in Fig. 5. The OCP was higher in the presence of $10^{-4} \mathrm{M}$ dichromate than in blank sodium chloride solution and increased further in a solution with a higher concentration of dichromate $\left(10^{-2} \mathrm{M}\right)$. The increase in the OCP with increasing dichromate concentration suggests either that the chromate acts as an oxidizing agent by providing an extra cathodic reaction or that the anodic kinetics are inhibited. In the presence of the smaller amount of dichromate $\left(10^{-4} \mathrm{M}\right)$ in $0.1 \mathrm{M} \mathrm{NaCl}$, the net current density decreased in the limiting ORR region. This net current density was slightly higher with $10^{-2} \mathrm{M}$ dichromate, perhaps due to the additional cathodic current for $\mathrm{Cr}(\mathrm{VI})$ reduction so dichromate apparently has several effects. 

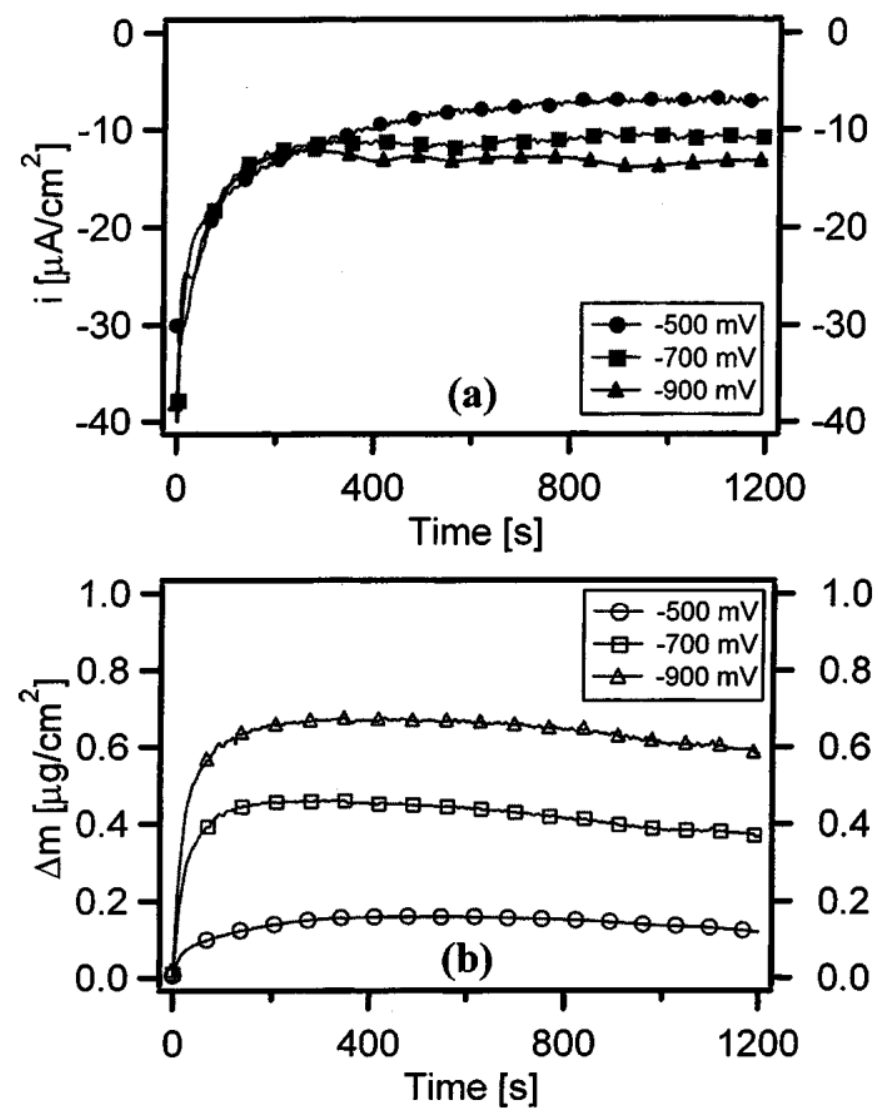

Figure 4. (a) Net current density and (b) mass change for $\mathrm{Al}_{2} \mathrm{Cu}$ during potentiostatic polarization in $0.1 \mathrm{M} \mathrm{NaCl}$ (pH 6.2).

The potentiodynamic polarization curves for $\mathrm{Al}-4 \mathrm{Cu}$ and $\mathrm{Al}_{2} \mathrm{Cu}$ in $0.1 \mathrm{MNaCl}$ with $0,10^{-}$ ${ }^{4}$, and $10^{-2} \mathrm{M}$ dichromate ions are shown in Fig. 6 and 7, respectively. They exhibited the same electrochemical trends as found for pure Al. The OCPs increased as the dichromate concentration increased, and the net current density decreased in the limiting ORR region in the presence of dichromate in solution.

Figures 8 and 9 show net current density and mass curves for pure $\mathrm{Al}$ during potentiostatic polarization at different potentials in the limiting ORR region in $0.1 \mathrm{M} \mathrm{NaCl}$ with $10^{-4}$ and $10^{-2} \mathrm{M}$ dichromate, respectively. The net current densities in the presence of dichromate were lower than in the blank sodium chloride solution. The mass showed a rapid decrease at the beginning of cathodic polarization and then decreased at a constant rate, similar to what was found in the blank sodium chloride solution. With dichromate in the solution, a mass increase associated with the formation of at least a monolayer of $\mathrm{Cr}$ (III) oxide/hydroxide on the $\mathrm{Al}$ surface, is predicted. This might occur immediately upon immersion in the dichromatecontaining solution and thus not be recorded by the EQCM. In the dichromate solutions, a steady state but lower mass loss region than blank sodium chloride solution was also observed. 


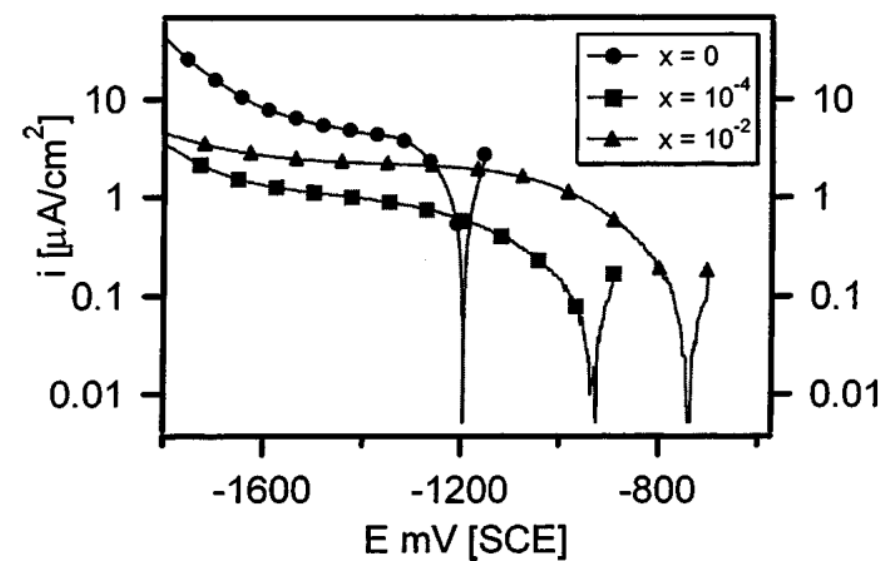

Figure 5. Potentiodynamic polarization curves of pure $\mathrm{Al}$ in $0.1 \mathrm{M} \mathrm{NaCl}$ with different concentrations of $\mathrm{Cr}_{2} \mathrm{O}_{7}^{-2}$ at a scan rate of $1 \mathrm{mV} / \mathrm{s}$.

The net current density and mass curves of $\mathrm{Al}-4 \mathrm{Cu}$ and $\mathrm{Al}_{2} \mathrm{Cu}$ during potentiostatic polarization in $0.1 \mathrm{M} \mathrm{NaCl}$ solution with $10^{-2}$ or $10^{-4} \mathrm{M}$ dichromate are shown in Fig. 10-13. The net current density for $\mathrm{Al}-4 \mathrm{Cu}$ and $\mathrm{Al}_{2} \mathrm{Cu}$ showed the same trend as pure $\mathrm{Al}$. The net current densities decreased slightly in the presence of dichromate. The magnitude of mass loss of Al$4 \mathrm{Cu}$ decreased with dichromate concentration, but was somewhat larger than the mass loss of pure $\mathrm{Al}$ in the same solution. $\mathrm{Al}_{2} \mathrm{Cu}$ showed similar mass change behavior as in $0.1 \mathrm{M} \mathrm{NaCl}$ solution in that the mass increased at the beginning of polarization. The mass was almost constant in the dichromate-containing solution after the initial increase because of a very low rate of dissolution in those solutions.

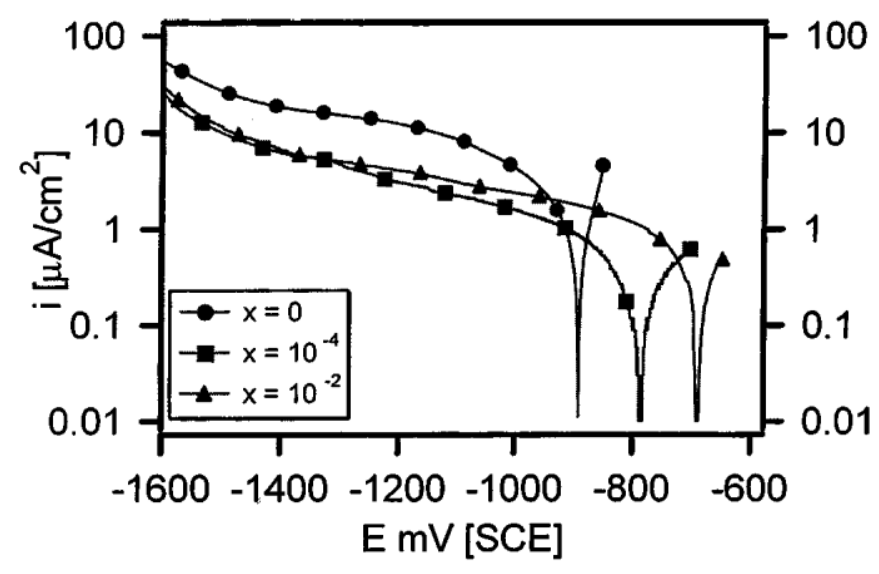

Figure 6. Potentiodynamic polarization curves of $\mathrm{Al}-4 \mathrm{Cu}$ in $0.1 \mathrm{M} \mathrm{NaCl}$ with different concentrations of $\mathrm{Cr}_{2} \mathrm{O}_{7} \quad$ at a scan rate of $1 \mathrm{mV} / \mathrm{s}$. 


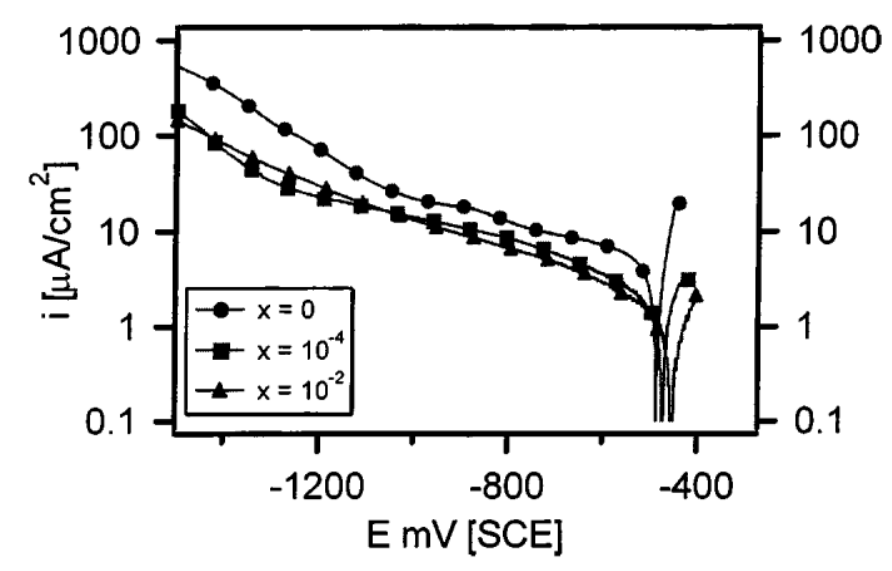

Figure 7. Potentiodynamic polarization curves of $\mathrm{Al}_{2} \mathrm{Cu}$ in $0.1 \mathrm{M} \mathrm{NaCl}$ with different concentrations of $\mathrm{Cr}_{2} \mathrm{O}_{7}^{-2}$ at a scan rate of $1 \mathrm{mV} / \mathrm{s}$.

Calculation of dissolution rate and cathodic current density.- The dissolution rate and true cathodic current density can be calculated from the measured mass loss and net current density. The mass loss rate at steady state, which is obtained by differentiating the mass curves, can be converted into a current density, $i_{\text {diss }}$, associated with Al oxidation and dissolution using Faraday's law. At steady state, the rate of chemical dissolution of the oxide film is balanced by the rate of oxide film formation. Assuming the thickness of oxide film is constant in the steadystate region, the mass loss rate can be directly related to the Al oxidation reaction rate.

The net current density, $i_{\text {net }}$, measured by the potentiostat is a sum of all of the reactions occurring on the surface

$$
i_{\text {net }}=i_{\text {cat }}+i_{\text {diss }}=i_{\mathrm{O}_{2}}+i_{\mathrm{H}_{2}}+i_{\mathrm{Cr}(\mathrm{VI})}+i_{\text {diss }}
$$

where $i_{\text {cat }}$ is the true cathodic current density, and $i_{\mathrm{O} 2}, i_{\mathrm{H} 2}$, and $i_{\mathrm{Cr}}(\mathrm{vI})$ are the cathodic current densities associated with oxygen reduction, hydrogen evolution, and chromate reduction, respectively. It can be assumed that the current associated with hydrogen evolution is small in comparison to oxygen reduction in an aerated neutral solution at potentials above those where water reduction is observed. As mentioned, chromate reduction might account for a monolayer of $\mathrm{Cr}$ (III) species, but the net charge associated with this layer formation passes at the beginning of cathodic polarization and is small. Therefore, the cathodic current associated with oxygen reduction is dominant in the limiting ORR regions. 

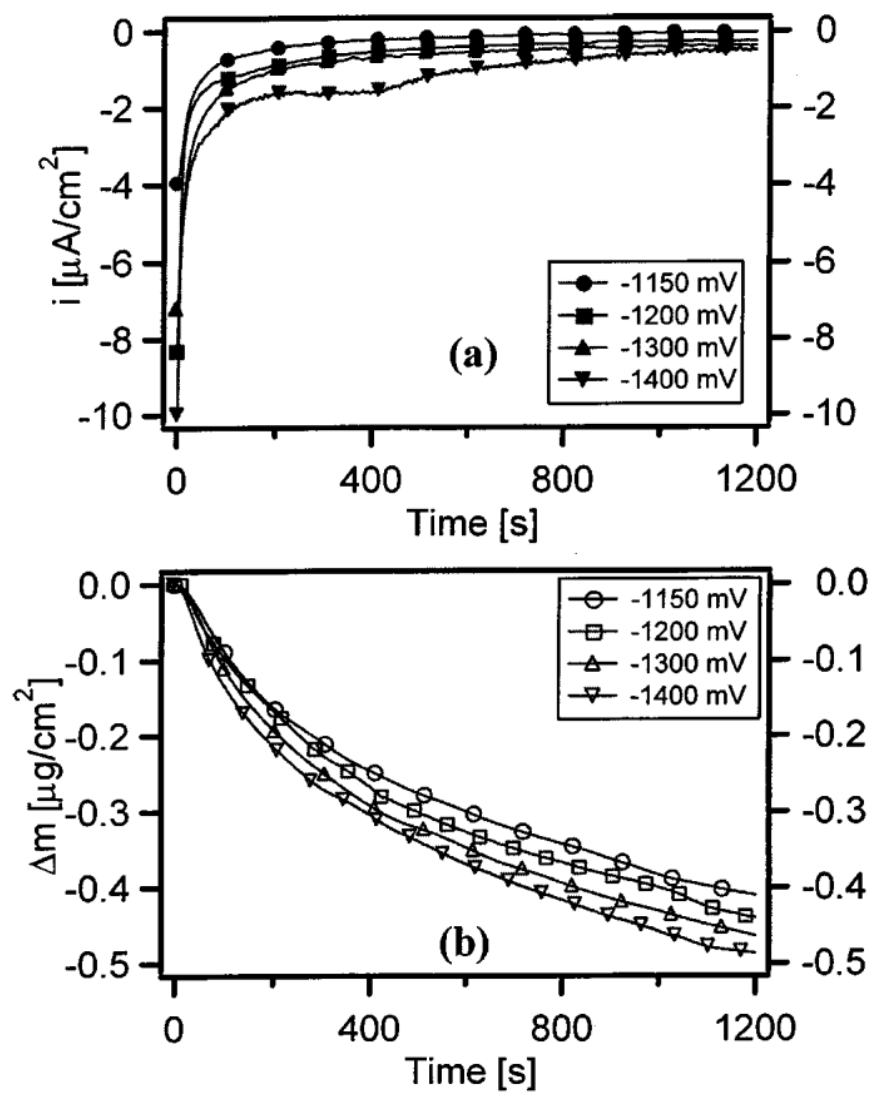

Figure 8. (a) Net current density and (b) mass change for pure $\mathrm{Al}$ during potentiostatic polarization in $0.1 \mathrm{M} \mathrm{NaCl}+$ $10^{-4} \mathrm{M} \mathrm{Cr}_{2} \mathrm{O}_{7}^{-2}(\mathrm{pH} 6.2)$.

Cathodic activity of aluminum, Al-4Cu, and $\theta$ phase.-Figure 14 summarizes the net current density, the cathodic corrosion rate determined from mass loss, and the true cathodic current density for pure $\mathrm{Al}, \mathrm{Al}-4 \mathrm{Cu}$, and $\mathrm{Al}_{2} \mathrm{Cu}$ in $0.1 \mathrm{M} \mathrm{NaCl}$ with $0,10^{-4}$, and $10^{-2} \mathrm{M}$ dichromate during potentiostatic polarization in the middle of the limiting current region. For pure $\mathrm{Al}$ and $\mathrm{Al}-4 \mathrm{Cu}$ in $0.1 \mathrm{M} \mathrm{NaCl}$, dissolution or cathodic corrosion occurred at a rate of about 3-4 $\mu \mathrm{A} / \mathrm{cm}^{2}$ in the limiting ORR region, and the cathodic current density ranged between 4 and 6 $\mu \mathrm{A} / \mathrm{cm}^{2}$, which is of the same order of magnitude as the dissolution rates. As a result, the true ORR rate was much larger than the measured net current density measured by the potentiostat, which does not reflect the true cathodic reaction rate for pure $\mathrm{Al}$ and $\mathrm{Al}-4 \mathrm{Cu}$.

It is interesting that cathodic current densities on the order of a few $\mathrm{mA} / \mathrm{cm}^{2}$ were sufficient to increase the local $\mathrm{pH}$ sufficiently for significant cathodic corrosion to occur. However, the $\mathrm{NaCl}$ solution is neutral and unbuffered, so its $\mathrm{pH}$ is easily altered. Furthermore, the sample was horizontal and only natural convection was occurring. 

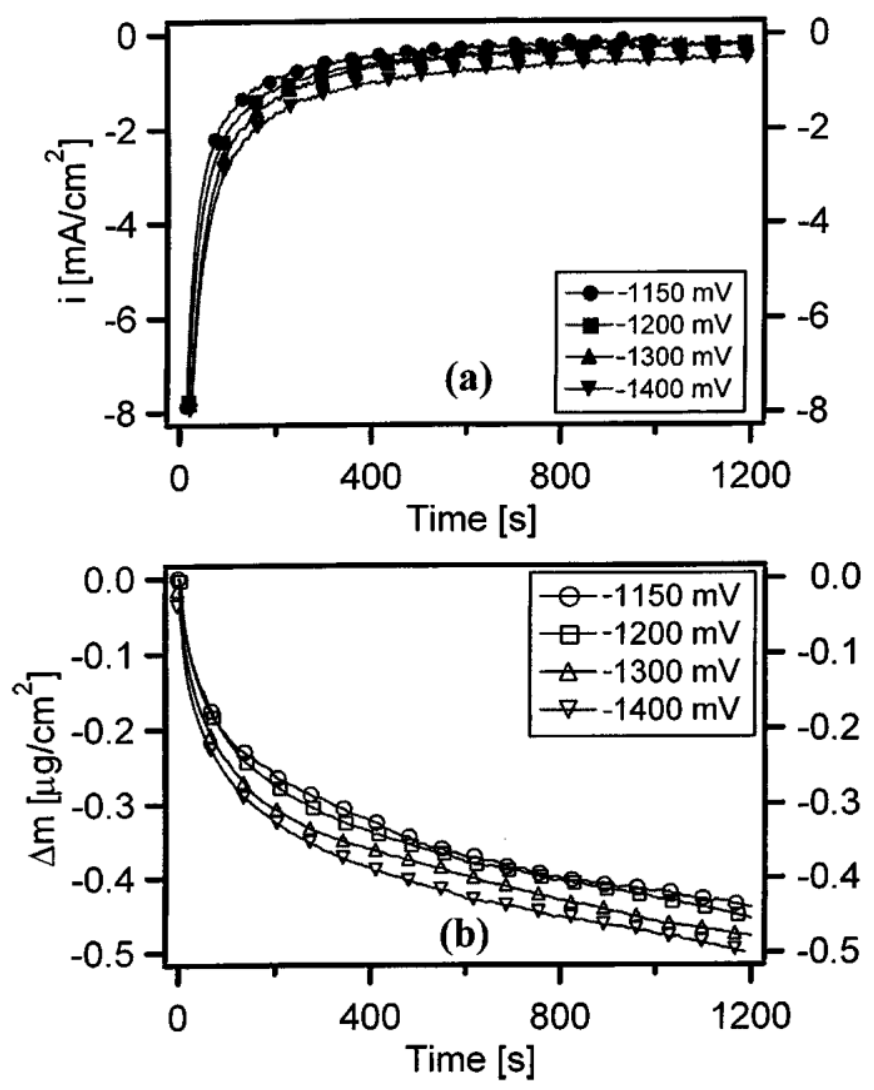

Figure 9. (a) Net current density and (b) mass change for pure $\mathrm{Al}$ during potentiostatic polarization in $0.1 \mathrm{M} \mathrm{NaCl}+$ $10^{-2} \mathrm{M} \mathrm{Cr}_{2} \mathrm{O}_{7}^{-2}(\mathrm{pH} 6.2)$.

For $\mathrm{Al}_{2} \mathrm{Cu}$ or $\theta$ phase in $0.1 \mathrm{M} \mathrm{NaCl}$, the true cathodic reaction rate was much higher, about $12 \mu \mathrm{A} / \mathrm{cm}^{2}$, than that for pure $\mathrm{Al}$ and the $\mathrm{Al}$ matrix in the same solution, showing the effect of the $\mathrm{Cu}$ content on the relative order of the ORR rates: $\theta$ phase $>\mathrm{Al}-4 \mathrm{Cu}>$ pure $\mathrm{Al}$. The true cathodic current density was similar to the measured net current density for $\mathrm{Al}_{2} \mathrm{Cu}$ because the dissolution rate was so small compared to the net current density. The cathodic corrosion rate for $\theta$ phase in $0.1 \mathrm{M} \mathrm{NaCl}$, about $1 \mu \mathrm{A} / \mathrm{cm}^{2}$, was lower than those for pure $\mathrm{Al}$ and $\mathrm{Al}-4 \mathrm{Cu}$ in the same solution. It should be noted that current density values are at different potentials for the different materials. At the same potential, the true cathodic reaction rate increased with the $\mathrm{Cu}$ content in the alloy, indicating that the cathodic reaction is kinetically easier as the $\mathrm{Cu}$ content in the alloy increases.

A considerable amount of cathodic corrosion occurred on cathodically polarized pure $\mathrm{Al}$ and $\mathrm{Al}-4 \mathrm{Cu}$, which exhibited true cathodic reaction rates on the same order of magnitude. Cathodic corrosion was almost independent of applied potential, suggesting that it is a chemical dissolution reaction, which depends on the concentration of $\mathrm{OH}^{-}$generated by oxygen reaction. In the pure chloride solution, the cathodic corrosion rate on $\mathrm{Al}-4 \mathrm{Cu}$ was slightly higher than that on pure $\mathrm{Al}$ due to the increased ORR rate. However, even though the ORR rate was much larger on $\mathrm{Al}_{2} \mathrm{Cu}$, less cathodic corrosion occurred. 

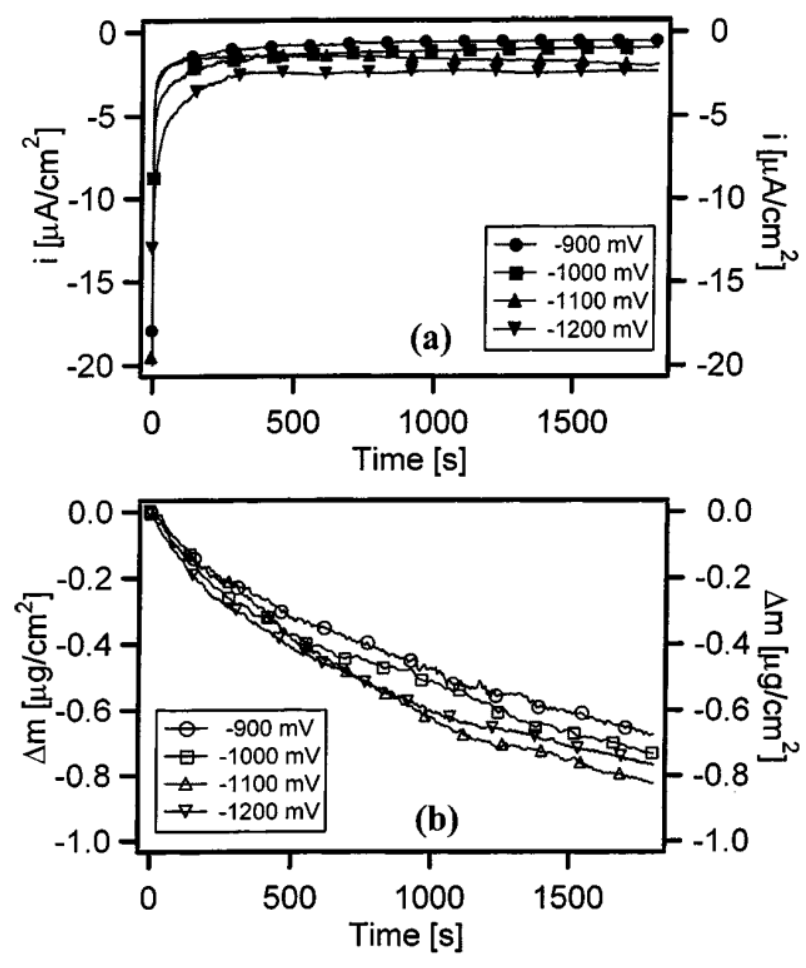

Figure 10. (a) Net current density and (b) mass change for $\mathrm{Al}-4 \mathrm{Cu}$ during potentiostatic polarization in $0.1 \mathrm{M} \mathrm{NaCl}$ $+10^{-4} \mathrm{M} \mathrm{Cr}_{2} \mathrm{O}_{7}^{-2}(\mathrm{pH} \mathrm{6.2)}$.
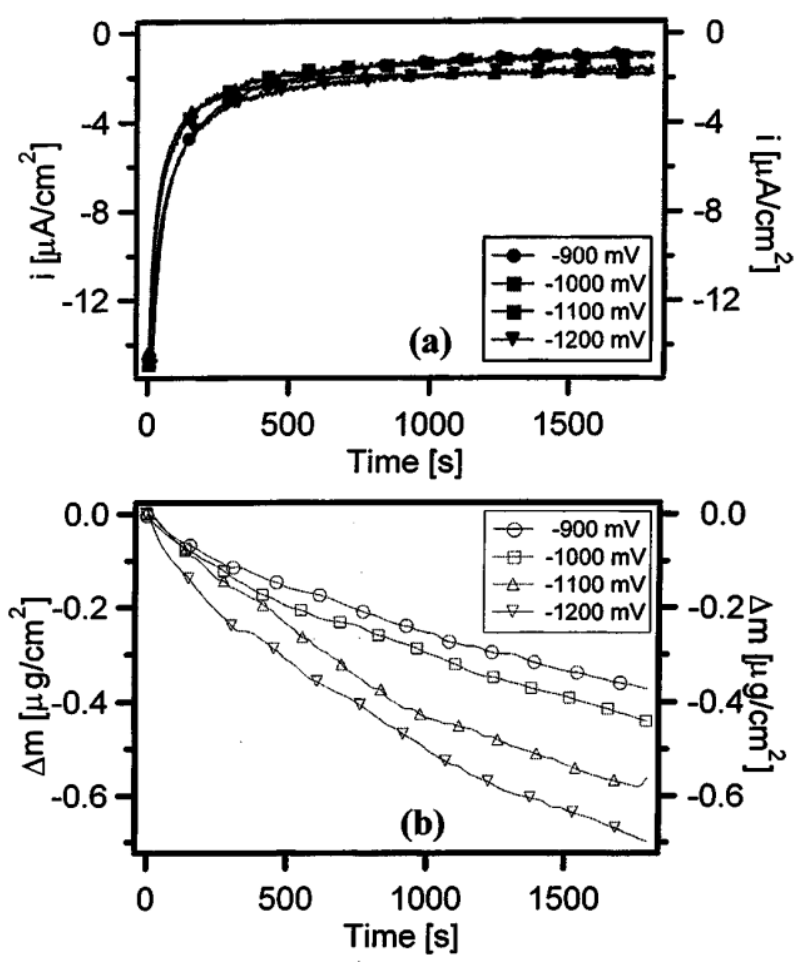

Figure 11. (a) Net current density and (b) mass change for $\mathrm{Al}-4 \mathrm{Cu}$ during potentiostatic polarization in $0.1 \mathrm{M} \mathrm{NaCl}$ $+10^{-2} \mathrm{M} \mathrm{Cr}_{2} \mathrm{O}_{7}^{-2}$ (pH 6.2). 

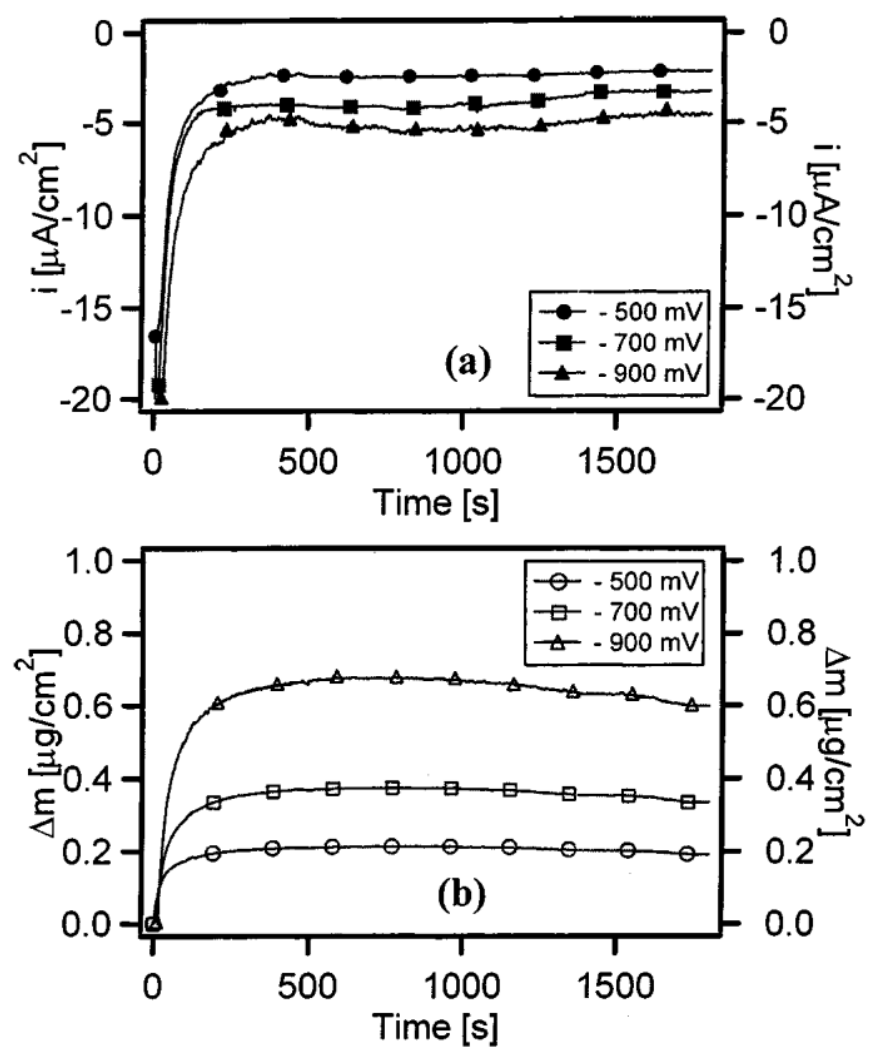

Figure 12. (a) Net current density and (b) mass change for $\mathrm{Al}_{2} \mathrm{Cu}$ during potentiostatic polarization in $0.1 \mathrm{M} \mathrm{NaCl}+$ $10^{-4} \mathrm{M} \mathrm{Cr}_{2} \mathrm{O}_{7}^{-2}$ (pH 6.2).

During cathodic corrosion, the electrons generated by $\mathrm{Al}$ oxidation (Eq. 2) are directly consumed by the oxygen reduction reaction (Eq. 3)

$$
\begin{aligned}
& \mathrm{Al}+4 \mathrm{OH}^{-} \rightarrow \mathrm{Al}(\mathrm{OH})_{4}^{-}+3 \mathrm{e}^{-} \\
& \mathrm{O}_{2}+2 \mathrm{H}_{2} \mathrm{O}+4 \mathrm{e}^{-} \rightarrow 4 \mathrm{OH}^{-}
\end{aligned}
$$

Hydroxide ions generated by oxygen reduction are consumed by the cathodic corrosion process. The local cell reaction involving cathodic corrosion is a sum of appropriate multiples of these reactions

$$
4 \mathrm{Al}+3 \mathrm{O}_{2}+6 \mathrm{H}_{2} \mathrm{O}+4 \mathrm{OH}^{-} \rightarrow 4 \mathrm{Al}(\mathrm{OH})_{4}^{-}
$$

When cathodic corrosion occurs (for pure $\mathrm{Al}$ and $\mathrm{Al}-4 \mathrm{Cu}$ ), the net current density, corresponding to the difference between cathodic current density and dissolution rate, is much smaller than the true oxygen reduction rate. The consumption of hydroxide ions by the cathodic corrosion reduces the concentration of $\mathrm{OH}^{-}$ions on the electrode, which promotes additional oxygen reduction if the current density is not limited by the mass transport of oxygen. Therefore, extra attention must 
be paid to the study of the cathodic kinetics of $\mathrm{Al}$ and $\mathrm{Al}$ alloys, on which the ORR rate is relatively low and the rate of cathodic corrosion is relatively high.
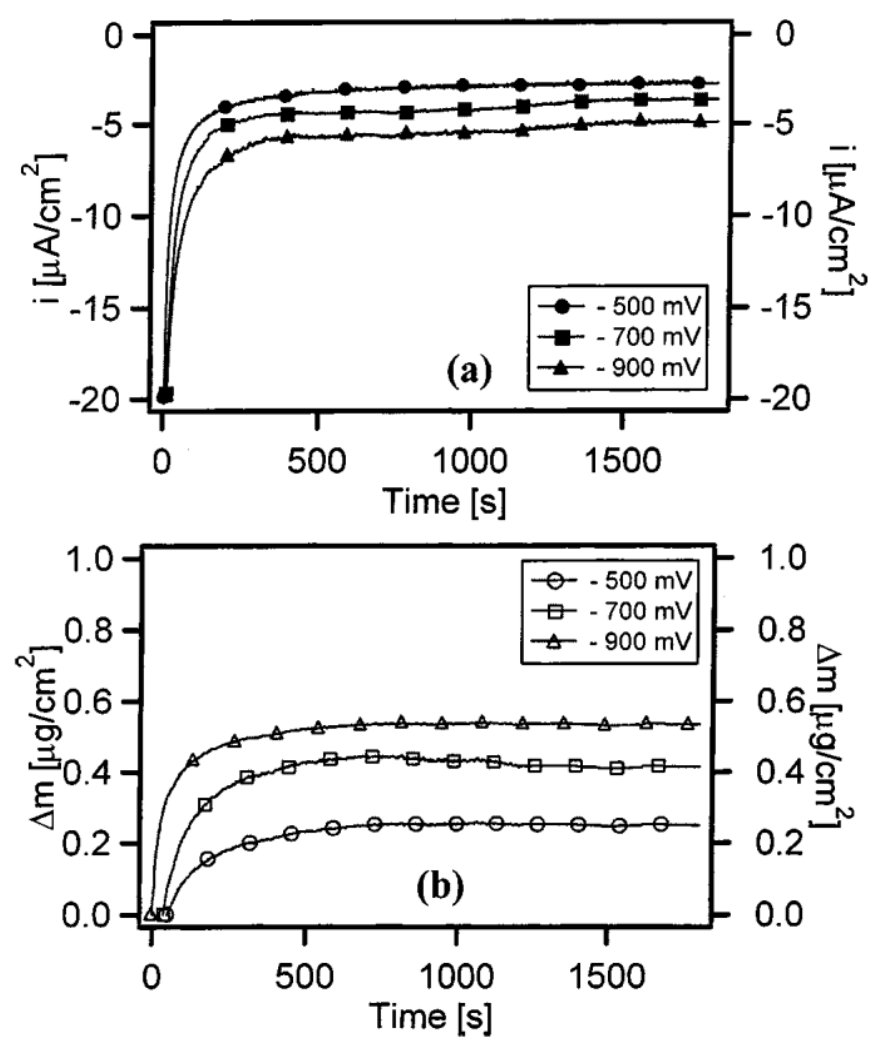

Figure 13. (a) Net current density and (b) mass change for $\mathrm{Al}_{2} \mathrm{Cu}$ during potentiostatic polarization in $0.1 \mathrm{M} \mathrm{NaCl}+$ $10^{-2} \mathrm{M} \mathrm{Cr}_{2} \mathrm{O}_{7}^{-2}$ (pH 6.2).

The lower $\mathrm{ORR}$ rate on pure $\mathrm{Al}$ and $\mathrm{Al}-4 \mathrm{Cu}$ suggests that electron transfer reaction (ETR) through the insulating Al oxide is the limiting step for the ORR on Al. ETRs on this Al oxide are not well-supported and the kinetics of ORR decrease with increasing Al oxide thickness. ${ }^{27}$ During cathodic polarization, even though the Al oxide film was already thinned by cathodic corrosion, the kinetics of ORR on pure $\mathrm{Al}$ and $\mathrm{Al}-4 \mathrm{Cu}$ were still controlled by electron transfer through the $\mathrm{Al}$ oxide. On the other hand, the high oxygen reduction rates on $\mathrm{Al}_{2} \mathrm{Cu}$ can be attributed to the $\mathrm{Cu}$ content of the surface oxide film. The presence of conducting metallic $\mathrm{Cu}^{0}$ was detected in the Al-rich native oxide on $\mathrm{Al}_{2} \mathrm{Cu}$ and $\mathrm{Al}_{2} \mathrm{CuMg}$. ${ }^{4,28}$ This metallic $\mathrm{Cu}^{0}$ in the $\mathrm{Al}$ oxide changes the conductivity of the oxide film on $\mathrm{Al}_{2} \mathrm{Cu}$, and enhances the kinetics of ORR on this phase to the extent that the limiting step of this phase can be mass-transport-limited $\mathrm{O}_{2}$ reduction.

Al oxide dissolution due to the increased local $\mathrm{pH}$ should lead to the enrichment of the $\mathrm{Cu}$ content on the surface during cathodic corrosion, which should make the surface more catalytic and accelerate oxygen reduction. However, these systems reached steady-state rates of oxygen evolution and mass loss. Metallic $\mathrm{Cu}$ exposed at the electrode surface can be nonfaradically detached from the electrode and be electrochemically redeposited on the surface. ${ }^{29}$ If this occurred, it would increase the measured net current density with no net mass change, so the true cathodic reaction rate might be smaller for $\mathrm{Al}-4 \mathrm{Cu}$ and $\mathrm{Al}_{2} \mathrm{Cu}$ than the 
summation of dissolution rate and net current density. However, it is expected that the cathodic current density associated with electrochemical redeposition of released $\mathrm{Cu}$ would be negligible compared to the ORR rate in aerated solution.

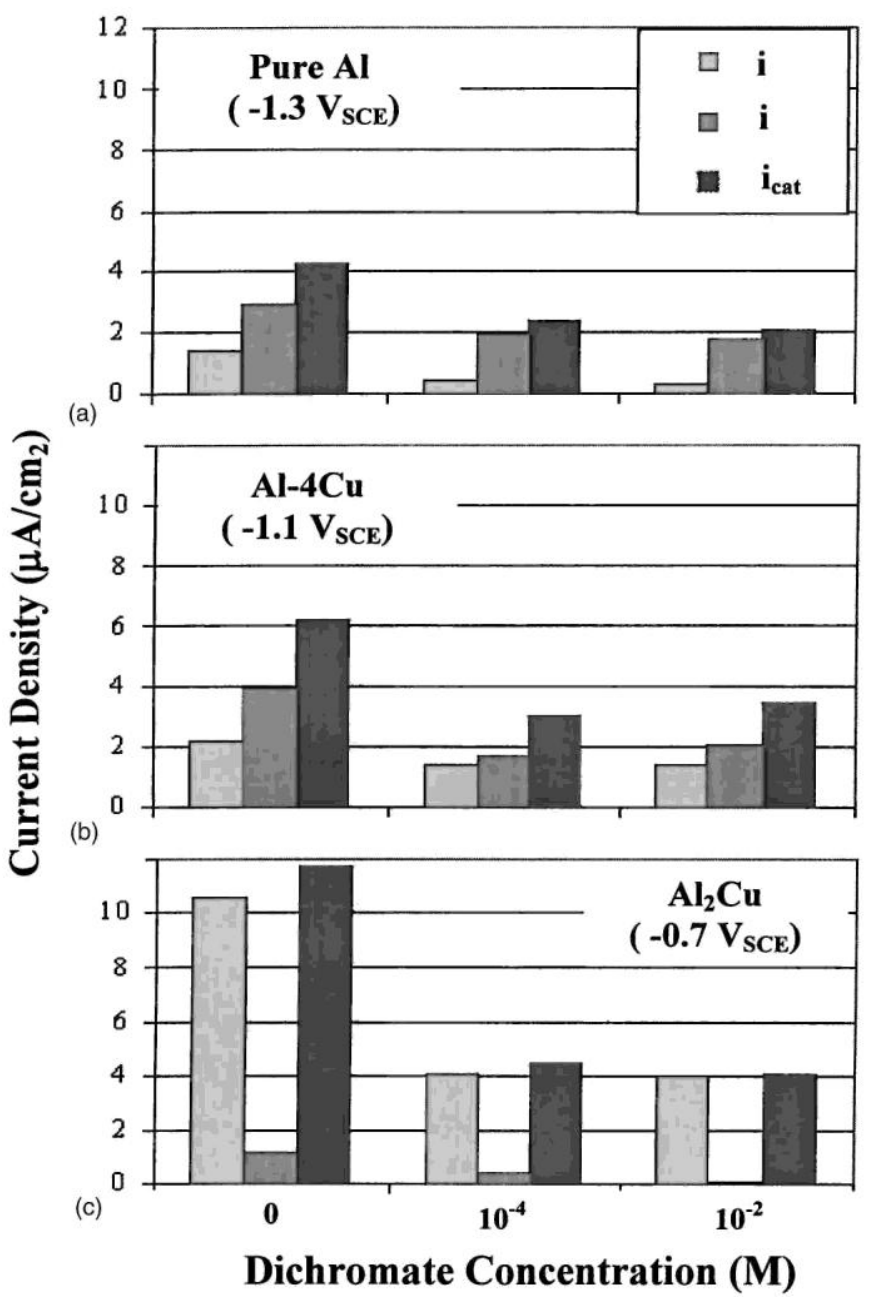

Figure 14. The measured net current density, the corrosion current density, and the true cathodic current density for pure $\mathrm{Al}(\mathrm{a}), \mathrm{Al}-4 \mathrm{Cu}(\mathrm{b})$, and $\mathrm{Al}_{2} \mathrm{Cu}(\mathrm{c})$ at indicated potentials as a function of dichromate concentration.

The effect of dichromate concentration on the dissolution rate and cathodic current density in the current-limited cathodic region was investigated in $0.1 \mathrm{MNaCl}$ containing $10^{-4}$ or $10^{-2} \mathrm{M}$ dichromate as shown in Fig. 14. The addition of $10^{-4} \mathrm{M}$ dichromate decreased the dissolution rate, or cathodic corrosion rate, for pure $\mathrm{Al}$ and $\mathrm{Al}-4 \mathrm{Cu}$ to about $50 \%$ of that in a blank sodium chloride solution. A further decrease in dissolution rate for pure Al was observed in the presence of $10^{-2} \mathrm{M}$ dichromate. The dissolution rate for $\mathrm{Al}_{2} \mathrm{Cu}$, which was smaller than that for pure $\mathrm{Al}$ and $\mathrm{Al}-4 \mathrm{Cu}$ in the pure chloride solution, became negligible, less than 0.3 $\mu \mathrm{A} / \mathrm{cm}^{2}$, in the presence of dichromate. Therefore, the net current density for $\mathrm{Al}_{2} \mathrm{Cu}$ was almost identical to the true cathodic reaction rate in dichromate-containing solutions.

The true cathodic reaction rates, or ORR rates, for pure $\mathrm{Al}$ and $\mathrm{Al}-4 \mathrm{Cu}$ in dichromate solution were also reduced compared with the blank sodium chloride solution. A larger decrease 
in ORR rate was observed for $\theta$ phase, which supported a faster ORR rate in $0.1 \mathrm{M} \mathrm{NaCl}$. The true cathodic reaction rate for $\mathrm{Al}_{2} \mathrm{Cu}$ decreased from 12 to $4 \mu \mathrm{A} / \mathrm{cm}^{2}$ in the presence of dichromate and was only slightly higher than those for pure $\mathrm{Al}$ and $\mathrm{Al}-4 \mathrm{Cu}$ in the same solution. The presence of dichromate in $0.1 \mathrm{M} \mathrm{NaCl}$ decreased both the dissolution rate and cathodic current density for pure $\mathrm{Al}, \mathrm{Al}-4 \mathrm{Cu}$, and $\mathrm{Al}_{2} \mathrm{Cu}$ during cathodic polarization. Since the OCPs of pure $\mathrm{Al}, \mathrm{Al}-4 \mathrm{Cu}$, and $\mathrm{Al}_{2} \mathrm{Cu}$ in $0.1 \mathrm{M} \mathrm{NaCl}$ with dilute dichromate concentration and neutral $\mathrm{pH}$ were much lower than the equilibrium potential for $\mathrm{Cr}$ (III) hydroxide formation, at least a $\mathrm{Cr}$ (III) monolayer was formed on the electrode surface according to the following reaction

$$
\mathrm{Cr}_{2} \mathrm{O}_{7}^{2-}+8 \mathrm{H}^{+}+6 \mathrm{e}^{-} \rightarrow 2 \mathrm{Cr}(\mathrm{OH})_{3}+\mathrm{H}_{2} \mathrm{O}
$$

There is a strong driving force for $\mathrm{Cr}(\mathrm{VI})$ reduction, and it might occur immediately upon immersion at open circuit or at the beginning of cathodic polarization in the dichromatecontaining solution accompanied by $\mathrm{Al}$ dissolution. This explains why monolayer formation of $\mathrm{Cr}(\mathrm{OH})_{3}$ was not detected by the EQCM measurements during cathodic polarization.

This Cr(III) oxide film can act as a physical barrier for cathodic corrosion, which is mainly caused by the chemical attack by $\mathrm{OH}^{-}$ions. The formation of an insoluble $\mathrm{Cr}$ (III) oxide layer could block direct contact of the $\mathrm{Al}$ oxide with the alkalinity generated by oxygen reduction. However, it should be noted that cathodic corrosion still occurred in dichromatecontaining solutions, so the $\mathrm{Cr}$ (III) oxide was not perfectly protective. It should also be noted that, since dichromate has a buffering ability, the presence of dichromate in solution also retarded local $\mathrm{pH}$ change on the electrode surface, resulting in less chemical dissolution by $\mathrm{OH}^{-}$ ions.

The $\mathrm{Cr}(\mathrm{III})$ oxide film and dichromate in solution also reduced the cathodic reaction rates, or ORR rates on pure $\mathrm{Al}, \mathrm{Al}-4 \mathrm{Cu}$, and $\mathrm{Al}_{2} \mathrm{Cu}$. The decrease in the ORR rate in dichromate solution can be attributed to several characteristics of a $\mathrm{Cr}$ (III) oxide layer on the electrode surface. The $\mathrm{Cr}$ (III) oxide film is electrically nonconductive so it can reduce the ORR rate by decreasing the conductivity of surface oxide films. The dichromate did not inhibit oxygen reduction on pure $\mathrm{Al}$ and $\mathrm{Al}-4 \mathrm{Cu}$ as much as on $\mathrm{Al}_{2} \mathrm{Cu}$. The oxide on $\mathrm{Al}$ and $\mathrm{Al}-4 \mathrm{Cu}$ is already relatively insulating, whereas $\mathrm{Al}_{2} \mathrm{Cu}$ has a more conductive surface film and can support higher rates of oxygen reduction. The less conductive $\mathrm{Cr}(\mathrm{III})$ oxide layer formed on $\mathrm{Al}_{2} \mathrm{Cu}$ in dichromate solution makes ETRs more difficult. ${ }^{6,26}$ Therefore, a greater decrease in ORR rate is expected for phases with a conductive oxide than for phases with an insulating oxide.

The $\mathrm{Cr}$ (III) oxide film formed on the electrode surface can inhibit oxygen reduction by occupying the active sites for oxygen chemisorption. Since the outer-sphere reduction mechanism of oxygen is kinetically slow, catalysis via $\mathrm{O}_{2}$ adsorption to the electrode surface is usually involved. The reduction of $\mathrm{Cr}(\mathrm{VI})$ and irreversible adsorption of $\mathrm{Cr}(\mathrm{III})$ to the electrode surface blocks sites of $\mathrm{O}_{2}$ adsorption.

The effect of dichromate as an oxidizer and the $\mathrm{Cr}$ (III) oxide layer also can reduce the cathodic reaction rate by thickening the oxide film on the surface. It was found from EIS measurements that chromate thickened the oxide films on $\mathrm{Cu}$ and $\mathrm{Al}_{20} \mathrm{Cu}_{2}(\mathrm{MnFe})_{3}$, resulting in an increase in corrosion resistance. ${ }^{6}$ The reduced cathodic corrosion also can have an effect on the reduced ORR rate on $\mathrm{Cu}$-rich intermetallic particles because it prevents further exposure of catalytic metallic $\mathrm{Cu}$ on the surface. 
Implications for corrosion inhibition of chromate on AA2024. - The effects of chromate on cathodic corrosion and cathodic reaction kinetics combine to make chromate a superior corrosion inhibitor for AA2024. In addition, the $\mathrm{Cr}$ (III) oxide film and chromate in the solution also protect the Al matrix from anodic dissolution. Even though it cannot be directly derived from results presented here, the OCP increase in dichromate-containing solution implies anodic inhibition of Al. The decrease in cathodic reaction rate results in the reduced anodic reaction rate and vice versa. For instance, suppressed fast cathodic ETR on $\mathrm{Cu}$-rich IMCs reduces the galvanic interaction between those IMCs and the surrounding $\mathrm{Al}$ matrix, and the reduced anodic dissolution of the $\mathrm{Al}$ matrix limits the $\mathrm{Cu}$-enrichment process on the surface, which would otherwise generate active catalytic $\mathrm{Cu}$ sites for oxygen reduction.

Table II. The net current densities at À700 $\mathrm{mV}_{\text {SCE }}$ for AA2024-T3 and intermetallic compounds in AA2024 without and with the presence of $\mathrm{Cr}(\mathrm{VI})$ in the solutions.

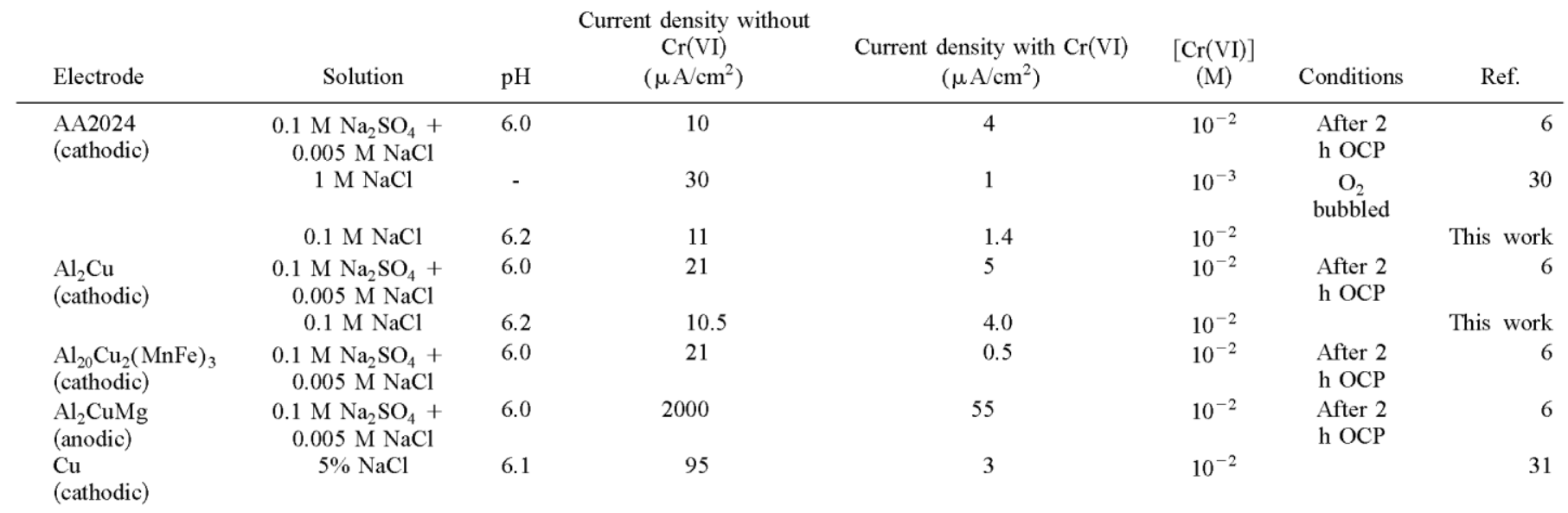

Table II summarizes the effects of chromate on the net current densities for AA2024 and $\mathrm{Cu}$-containing IMCs as reported in the literature ${ }^{6,30,31}$ and from this study. Comparison of these data is complicated by the fact that they were collected in different solutions and under different experimental conditions. Nonetheless, some general trends can be discerned. Chromate is effective at decreasing the net cathodic current densities on the more noble phases such as $\mathrm{Cu}$ and $\mathrm{Al}_{20} \mathrm{Cu}_{2}(\mathrm{MnFe})_{3}$, making them less than several $\mathrm{mA} / \mathrm{cm}^{2}$. It also decreases the anodic reaction rate on $\mathrm{Al}_{2} \mathrm{CuMg}$, which is about $60 \%$ of second-phase particles in AA2024. ${ }^{32}$ The reduced oxygen reduction reactions on $\theta$ phase and $\mathrm{Al}-\mathrm{Cu}-\mathrm{Fe}-\mathrm{Mn}$ phase by chromate generates less hydroxide ions, which attack the surrounding Al matrix and IMCs themselves, so it suppresses further development of active cathodic sites from $\mathrm{Cu}$ redistribution and exposition of catalytic $\mathrm{Cu}$ on the alloy surface. S-phase particles, which can provide a $\mathrm{Cu}$ source for $\mathrm{Cu}$ redistribution after it is dealloyed and thus generate more active cathodic sites for ORR, ${ }^{2,32}$ are anodically inhibited, which further decreases the active cathodic sites for oxygen reduction. These combined effects make chromate a more efficient oxygen reduction inhibitor and subsequently corrosion inhibitor for AA2024 than for $\mathrm{Al}_{2} \mathrm{Cu}$ or $\mathrm{Al}-4 \mathrm{Cu}$ individually. 


\section{Conclusions}

The cathodic corrosion of thin film analogs of phases in AA2024 was characterized by the EQCM technique. Thin films of pure $\mathrm{Al}, \mathrm{Al}-4 \% \mathrm{Cu}$, and $\mathrm{Al}_{2} \mathrm{Cu}$ were studied at cathodic potentials in the limiting ORR region in $0.1 \mathrm{M} \mathrm{NaCl}$ containing different amounts of dichromate. The following were found.

1. As the $\mathrm{Cu}$ content in the Al-Cu binary alloy system increased, open-circuit potential and net current density at cathodic potentials increased and the onset of hydrogen evolution occurred at higher potentials in $0.1 \mathrm{M} \mathrm{NaCl}$.

2. For pure $\mathrm{Al}$ and $\mathrm{Al}-4 \mathrm{Cu}$ in $0.1 \mathrm{M} \mathrm{NaCl}$, a considerable amount of cathodic corrosion, ranging up to about $4 \mu \mathrm{A} / \mathrm{cm}^{2}$, occurred at cathodic potentials in the limiting ORR region. The cathodic corrosion rate was on the same order of magnitude as the true cathodic reaction rates.

3. Cathodic corrosion rate for $\mathrm{Al}_{2} \mathrm{Cu}$ in $0.1 \mathrm{M} \mathrm{NaCl}$ was about $1 \mu \mathrm{A} / \mathrm{cm}^{2}$ in the limiting ORR region and was much smaller than the true cathodic reaction rate for this phase.

4. In the presence of dichromate in $0.1 \mathrm{M} \mathrm{NaCl}$ solution, the open-circuit potential increased, and both the cathodic corrosion rate and oxygen reduction rate decreased for pure $\mathrm{Al}$, $\mathrm{Al}-4 \mathrm{Cu}$, and $\mathrm{Al}_{2} \mathrm{Cu}$.

5. True cathodic current densities and cathodic corrosion rates for pure $\mathrm{Al}, \mathrm{Al}-4 \mathrm{Cu}$, and $\mathrm{Al}_{2} \mathrm{Cu}$ were weakly dependent on applied potential and chromate concentration while they showed stronger dependencies on the content of $\mathrm{Cu}$.

6. A larger decrease in the ORR rate was observed on $\mathrm{Al}_{2} \mathrm{Cu}$ than on pure $\mathrm{Al}$ and $\mathrm{Al}-4 \mathrm{Cu}$ in dichromate-containing solution because of the insulating $\mathrm{Al}$ oxide films on $\mathrm{Al}$ and $\mathrm{Al}-4 \mathrm{Cu}$, which support slower electron transfer rates.

7. For the corrosion of AA2024, the effects of chromate on both dissolution and cathodic reaction rates combine to make chromate a more efficient corrosion inhibitor than for the individual phases in the alloy.

\section{Acknowledgments}

This work was supported by the United States Air Force Office of Scientific Research Grant no. F49620-96-1-0479 under the guidance of Dr. Paul Trulove.

The Ohio State University assisted in meeting the publication costs of this article.

\section{References}

1. R. G. Buchheit, J. Electrochem. Soc., 142, 3994 (1995).

2. N. Dimitrov, J. A. Mann, M. Vukmirovic, and K. Sieradzki, J. Electrochem. Soc., 147, 3283 (2000).

3. P. Schmutz and G. S. Frankel, J. Electrochem. Soc., 145, 2285 (1998).

4. R. G. Buchheit, R. P. Grant, P. F. Hlava, B. McKenzie, and G. L. Zender, J. Electrochem. Soc., 144, 2621 (1997).

5. N. Dimitrov, J. A. Mann, and K. Sieradzki, J. Electrochem. Soc., 146, 98 (1999).

6. O. Ilevbare and J. R. Scully, Corrosion (Houston), 57, 134 (2001).

7. J. Zhao, G. S. Frankel, and R. L. McCreery, J. Electrochem. Soc., 145, 2258 (1998).

8. P. Leblanc and G. S. Frankel, J. Electrochem. Soc., 149, B239 (2002).

9. W. J. Clark and R. L. McCreery, J. Electrochem. Soc., 149, B379 (2002).

10. W. J. Clark, J. D. Ramsey, R. L. McCreery, and G. S. Frankel, J. Electrochem. Soc., 149, B179 (2002).

11. E. P. G. T. van der Ven and H. Koelmans, J. Electrochem. Soc., 123, 143 (1976).

12. A. R. Despic, J. Radosevic, P. Dabic, and M. Kliskic, Electrochim. Acta, 35, 1743 (1990).

13. H. Takahashi, K. Fujiwara, and M. Seo, Corros. Sci., 36, 689 (1994).

14. G. Sauerbrey, Z. Phys., 155, 206 (1959). 
15. S. Bruckenstein and M. Shay, Electrochim. Acta, 30, 1295 (1985).

16. J. C. Hoogvliet and W. P. van Bennekom, Electrochim. Acta., 47, 599 (2001).

17. R. Schumacher, A. Muller, and W. Stockel, J. Electroanal. Chem., 219, 311 (1987).

18. D. Jope, J. Sell, H. W. Pickering, and K. G. Weil, J. Electrochem. Soc., 142, 2170 (1995).

19. M. Fonsati, F. Zucchi, and G. Trabanelli, Electrochim. Acta, 44, 311 (1998).

20. P. Schmutz and D. Landolt, Electrochim. Acta, 45, 899 (1999).

21. P. Schmutz and D. Landolt, Corros. Sci., 41, 2143 (1999).

22. M. Hepel and E. Cateforis, Electrochim. Acta, 46, 3801 (2001).

23. Y. Baek, M.S. Thesis, The Ohio State University, Columbus, OH (2002).

24. G. S. Frankel, J. R. Scully, and C. V. Jahnes, J. Electrochem. Soc., 143, 1834 (1996).

25. T Ramgopal, P. Schmutz, and G. S. Frankel, J. Electrochem. Soc., 148, B348 (2001).

26. G. O. Ilevbare and J. R. Scully, J. Electrochem. Soc., 148, B196 (2001).

27. J. R. Scully, D. E. Peebles, A. D. R. Frear, Jr., and C. R. Hills, Metall. Trans. A, 23, 2641 (1992).

28. J. R. Scully, T O. Knight, R. G. Buchheit, and D. E. Peebles, Corros. Sci, 35, 185 (1993).

29. R. G. Buchheit, M. A. Martinez, and L. P. Montes, J. Electrochem. Soc., 147, 119 (2000).

30. A. Sehgal, G. S. Frankel, B. Zoofan, and S. Rokhlin, J. Electrochem. Soc., 147, 140 (2000).

31. M. Kendig and S. Jeanjaquet, Unpublished results, 2001.

32. R. G. Buchheit, L. P. Montes, M. A. Martinez, J. Michael, and P. F Hlava, J. Electrochem. Soc., 146, 4424 (1999). 